\title{
FEASIBILITY OF USING Festuca arundinacea FOR REGENERATION OF GRASSLANDS BY MEANS OF FULL CULTIVATION METHOD ON ORGANIC SOIL
}

\section{MOŻLIWOŚCI WYKORZYSTANIA Festuca arundinacea DO REGENERACJI UŻYTKÓW ZIELONYCH METODĄ PEŁNEJ UPRAWY NA GLEBIE ORGANICZNEJ}

\author{
Department of Soil Science, Grassland Science and Environmental Chemistry, West Pomeranian \\ University of Technology, Szczecin, Poland \\ ${ }^{1}$ Landesforschungsanstalt für Landwirtschaft und Fischerei MV in Dummerstorf, Germany \\ 2Department of Agronomy, West Pomeranian University of Technology, Szczecin, Poland
}

\begin{abstract}
Streszczenie. Badania przeprowadzono w dolinie rzeki Randow, na użytkach zielonych należących do gospodarstwa rolnego Raminer Agrar GmbH\&Co (Niemcy). Odnowę użytków zielonych, zlokalizowanych na glebie organicznej, przeprowadzono metodą pełnej uprawy. Badaniami objęto mieszanki z dominującym udziałem Festuca arundinacea. Ocena obejmowała charakterystykę składu florystycznego, zadarnienie i ogólny wygląd runi łąkowej, poziom plonowania i równomierność produkcji biomasy w sezonie wegetacyjnym. Średnie wyniki z lat badań (2012, 2013 i 2015) wykazały, że zastosowane mieszanki odznaczały się zbliżonym poziomem plonowania, chociaż należy wyróżnić mieszankę Festuca arundinacea z Dactylis glomerata - po 50\%; na uwagę zasługuje także mieszanka Festuca arundinacea z Lolium perenne. Jeżeli chodzi o ocenę odmian Festuca arundinacea ('Lipalma', 'Koral', 'Hykor', 'Fawm'), to największym potencjałem produkcyjnym odznaczała się odmiana 'Hykor'. Do wielokośnego użytkowania runi łąkowej nawet pięciokrotnie mniej przydatne są Festuca pratensis i Phleum pratense. Uzyskane wyniki wskazują, że Festuca arundinacea nadaje się do regeneracji użytków zielonych na glebach organicznych, przy stosowaniu w mieszankach z Dacylis glomerata, Lolium perenne i Festulolium.
\end{abstract}

Key words: organic soil, grass mixtures, yields, regeneration by full cultivation method, floristic composition, grassland.

Słowa kluczowe: gleba organiczna, mieszanki trawiaste, plony, regeneracja metodą pełnej uprawy, skład florystyczny, użytek zielony.

\section{INTRODUCTION}

The structure of meadow communities determines the production potential and quality of feed (Grzegorczyk 1993; Trąba 1994). Floristic composition on hydrogenic soils, e.g. peat-muck, is characterized by dynamic succession (Baryła 1997; Kamiński 2000).

Corresponding author - Adres do korespondencji: Henryk Czyż, Department of Soil Science, Grassland Science and Environmental Chemistry, West Pomeranian University of Technology, Szczecin, Juliusza Słowackiego 17, 71-434 Szczecin, Poland, e-mail: Henryk.Czyz@zut.edu.pl 
Based on the studies conducted by Baryła and Kulik (2012), besides Dactylis glomerata, Lolium perenne, Festulolium braunii and Phleum pratense, also Festuca pratensis and Festuca arundinacea are suitable for regeneration mixtures in appropriate meadow habitats. Petersen (1981); Schmaler and Barthelmes (2015), as well as Troxler and Mitztal (1983) argue that different varieties of Festuca arundinacea are characterized by good winterhardness and high resistance to unfavorable habitat conditions. This is confirmed by studies of Suter et al. (2009), who reported usefulness of Festuca arundinacea under variable climatic conditions of Switzerland and concluded that it can be an important ingredient in grass mixtures on intensively utilized pasture. Nussbaum (2015) and Niemeläinen et al. (2001) found that Festuca arundinacea is a species of high yielding, but not demanding. In opinion of Nussbaum (2015), due to well developed root system, it tolerates periods of drought and low temperatures and is suitable for habitats with varying humidity balance. Schubiger et al. (1997) highlight the low interest in this species in practice due to the high content of silica and hardness of its leaves.

The purpose of the study was to determine the suitability of Festuca arundinacea for regeneration mixtures on grassland located on organic soils.

\section{MATERIAL AND METHODS}

The meadow study carried out on grasslands located on the organic soils in the Randow river valley covered the years 2012, 2013 and 2015. In 2011, the grassland in question, which belonged to the farm Raminer Agrar $\mathrm{GmbH} \&$ Co (Germany), was regenerated by the full cultivation method. The meadow experiment was established by split-block method in four replicates. The area of a single plot was $10 \mathrm{~m}^{2}$. Following grass species were used to regenerate the grasslands: tall fescue (Festuca arundinacea), Festulolium braunii, perennial rye-grass (Lolium perenne), Kentucky bluegrass (Poa pratensis), orchard grass (Dactylis glomerata), timothy-grass (Phleum pretense), and meadow fescue (Festuca pratensis). Composition of the grass mixtures used for sowing in the individual experiments is shown in Table 1. Pratotechnical treatments performed within this method frameworks included: spraying with Roundup herbicide, plowing at a depth of $25 \mathrm{~cm}$, rolling, surface treatment, grass seed sowing - first decade of September 2011, post-seeding rolling. No fertilization was used before sowing. In the years of full performance, the following treatments were carried out: dragging, rolling, fertilizing, and mowing. The collected biomass was allocated to hay-silage. In the first year of use (2012), three cuts were harvested, in the second year (2013) - four cuts, and in the fourth year (2015) - five cuts.

Meadow sward was harvested in the shooting / earing beginning phase at triple harvest, and from the end of the tillering to the end of shooting - at five harvests. At the time of spring treatments - dragging and rolling, the multi-constituent fertilizer was applied - NPK (MgS) (5-16-24-(4-7)), that introduced to the soil: $15 \mathrm{~kg} \mathrm{~N}, 21 \mathrm{~kg} \mathrm{P}, 60 \mathrm{~kg} \mathrm{~K}, 7 \mathrm{~kg} \mathrm{Mg}$, and $21 \mathrm{~kg} \mathrm{~S}$ per 1 ha. In addition, $72 \mathrm{~kg} \cdot \mathrm{ha}^{-1} \mathrm{~N}$ was used in the form of ammonium nitrate and urea (AHL). For the second cut, nitrogen rate was $65 \mathrm{~kg} \cdot \mathrm{ha}^{-1}$, while for the third one $-36 \mathrm{~kg} \cdot \mathrm{ha}^{-1} \mathrm{~N}$, also in form of $\mathrm{AHL}$; in the case of four cuts, $36 \mathrm{~kg} \cdot \mathrm{ha}^{-1} \mathrm{~N}$ was used for the third cut and $36 \mathrm{~kg} \cdot \mathrm{ha}^{-1} \mathrm{~N}$ for the fourth one. In the last year of study (2015) $65 \mathrm{~kg}$ of nitrogen was 
applied in spring in the form of $\mathrm{AHL}$, along with $140 \mathrm{~kg} \cdot \mathrm{ha}^{-1}$ of DAP fertilizer $(18 \% \mathrm{~N}$, $\left.46 \% \mathrm{P}_{2} \mathrm{O}_{5}\right)$ and $300 \mathrm{~kg} \cdot \mathrm{ha}^{-1}$ KornKali $\left(40 \% \mathrm{~K}_{2} \mathrm{O}, 6 \% \mathrm{MgO}, 3 \% \mathrm{Na}, 4 \% \mathrm{~S}\right)$. After harvest of the first cut, KornKali was applied at the rate of $250 \mathrm{~kg} \cdot \mathrm{ha}^{-1}$ in combination with $\mathrm{AHL}-$ $180 \mathrm{dm}^{3} \cdot \mathrm{ha}^{-1}$. After second cut, fertilization referred only to nitrogen, the rate of which was $54 \mathrm{~kg} \cdot \mathrm{ha}^{-1} \mathrm{~N}$, in the form of AHL. The floristic composition of each plot (4 replicates) was assessed by botanical-weight method (Filipek 1970). Floristic composition of the first cut was presented as the results in the other cuts were similar. Dry matter content in meadow sward was determined by sampling $1 \mathrm{~m}^{2}$ in each replicate during the harvest of the individual cuts. The product of green matter yield and dry matter content was the yield of dry matter. The dry weight yields were statistically analyzed using a classical variance analysis and the significance of the variance was determined using the Tukey test at the significance level $p \leq 0.05$.

Characterizing the water conditions of meadow habitats in the area of conducted research, it should be stated that rain water and groundwater was only available for plants. In the vegetation periods (IV-X) of the studied years, the highest rainfall $(370.4 \mathrm{~mm})$ was recorded in 2012, then $311.3 \mathrm{~mm}$ in 2013, while the lowest $(305.5 \mathrm{~mm}$ ) - in 2015. Referring to the multi-year average $(378.9 \mathrm{~mm})$, similar value was found in 2012 . Regarding the distribution of precipitation in the growing seasons, year 2012 was comparable to the multiyear period, and 2015 was the most different one. When estimating the level of groundwater, it should be noted that the greatest amplitude $(0-76 \mathrm{~cm})$ was recorded in 2012, and the smallest $(45-88 \mathrm{~cm})$ - in 2015.

\section{RESULTS AND DISCUSSION}

The pattern of results showing the meadow grass species structure indicates that it depended on the composition of mixtures used for sowing the individual objects. It is important to note the very small proportion of species spontaneously entering the meadow sward, and sporadically occurring species were Poa trivialis, Poa pratensis, Festuca rubra, Agrostis stolonifera, Agropyron repens, and Taraxacum officinale. The individual objects exhibited high floral stability during the study period (2012-2015), although the most labile species was Lolium perenne. In object 7 , which was sown with only two species in equal proportions - Festuca arundinacea and Lolium perenne - 50\% each, a decrease in Lolium perenne share for the surplus Festuca arundinacea was observed. The share of Lolium perenne decreased from $50 \%$ in 2012 to $28 \%$ in 2015 . In object 6 , where Festuca arundinacea made up $30 \%$ and Lolium perenne $70 \%$ in the regenerative mixture, these relations were at the assumed level of $67 \%$ Festuca arundinacea and $31 \%$ Lolium perenne in the fourth year of full performance. A similarity was found for the object 12 sown with the mixture $70 \%$ Festuca arundinacea and 30\% Lolium perenne; in the last year of the study (2015), the proportion of these species in the sward was $71 \%$ and $27 \%$, respectively. If the share of Lolium perenne was small (5-10\%), it was not subject to change in the individual years of the study. The data presented show that the succession was aimed at shaping a certain ratio between Festuca arundinacea and Lolium perenne. The results confirming great durability of Festuca arundinacea in post-bog habitats were reported by Grzegorczyk et al. (1995). The 
results pattern (Table 1) indicates that Lolium perenne occurring in the community along with Dactylis glomerata and Festuca arundinacea is highly competitive and is a "filler" in the thickening of the sward.

Table 1. Floristic composition of meadow sward in the years 2012, 2013, 2015

Tabela 1. Skład florystyczny runi łąkowej w latach 2012, 2013, 2015

\begin{tabular}{|c|c|c|c|c|c|}
\hline \multirow{2}{*}{$\begin{array}{l}\text { Objects } \\
\text { Obiekty }\end{array}$} & \multirow{2}{*}{$\begin{array}{l}\text { Species } \\
\text { Gatunki }\end{array}$} & \multirow{2}{*}{$\begin{array}{c}\text { Share in the mixture } \\
\text { Udział w mieszance } \\
{[\%]}\end{array}$} & \multicolumn{3}{|c|}{$\begin{array}{c}\text { Share in the sward } \\
\text { Udział w runi [\%] }\end{array}$} \\
\hline & & & 2012 & 2013 & 2015 \\
\hline \multirow{2}{*}{1} & Festuca arundinacea ('Lipalma') & 100 & 99 & 100 & 97 \\
\hline & Other species - Inne gatunki & & 1 & 0 & 3 \\
\hline \multirow{2}{*}{2} & Festuca arundinacea ('Kora') & 100 & 100 & 100 & 99 \\
\hline & Other species - Inne gatunki & & 0 & 0 & 1 \\
\hline \multirow[t]{2}{*}{3} & Festuca arundinacea ('Hykor') & 100 & 100 & 100 & 99 \\
\hline & Other species - Inne gatunki & & 0 & 0 & 1 \\
\hline \multirow{3}{*}{4} & Festuca arundinacea ('Fawn') & 100 & 100 & 100 & 99 \\
\hline & Other species - Inne gatunki & & 0 & 0 & 1 \\
\hline & Festuca arundinacea & 20 & 22 & 28 & 33 \\
\hline \multirow{3}{*}{5} & Festuca pratensis & 40 & 39 & 37 & 36 \\
\hline & Phleum pratense & 20 & 18 & 16 & 14 \\
\hline & Lolium perenne & 20 & 21 & 19 & 17 \\
\hline \multirow{3}{*}{6} & Festuca arundinacea & 30 & 43 & 77 & 67 \\
\hline & Lolium perenne & 70 & 56 & 22 & 31 \\
\hline & Other species - Inne gatunki & & 1 & 1 & 2 \\
\hline \multirow{3}{*}{7} & Festuca arundinacea & 50 & 48 & 68 & 69 \\
\hline & Lolium perenne & 50 & 52 & 32 & 28 \\
\hline & Other species - Inne gatunki & & 0 & 0 & 3 \\
\hline \multirow{3}{*}{8} & Festuca arundinacea & 50 & 46 & 39 & 43 \\
\hline & Festulolium braunii & 50 & 54 & 61 & 51 \\
\hline & Other species - Inne gatunki & & 0 & 0 & 6 \\
\hline \multirow{3}{*}{9} & Festuca arundinacea & 50 & 63 & 44 & 45 \\
\hline & Dactylis glomerata & 50 & 36 & 54 & 52 \\
\hline & Other species - Inne gatunki & & 1 & 2 & 3 \\
\hline \multirow{4}{*}{10} & Festuca arundinacea & 50 & 66 & 42 & 45 \\
\hline & Dactylis glomerata & 45 & 26 & 52 & 43 \\
\hline & Lolium perenne & 5 & 6 & 6 & 10 \\
\hline & Other species - Inne gatunki & & 0 & 0 & 2 \\
\hline \multirow{4}{*}{11} & Festuca arundinacea & 70 & 67 & 76 & 67 \\
\hline & Phleum pratense & 20 & 25 & 16 & 18 \\
\hline & Poa pratensis & 10 & 8 & 8 & 13 \\
\hline & Other species - Inne gatunki & & 0 & 0 & 2 \\
\hline \multirow{3}{*}{12} & Festuca arundinacea & 70 & 85 & 74 & 71 \\
\hline & Lolium perenne & 30 & 15 & 26 & 27 \\
\hline & Other species - Inne gatunki & & 0 & 0 & 2 \\
\hline \multirow{3}{*}{13} & Festuca arundinacea & 80 & 71 & 82 & 76 \\
\hline & Lolium perenne & 20 & 29 & 18 & 21 \\
\hline & Other species - Inne gatunki & & & & 3 \\
\hline \multirow{3}{*}{14} & Festuca arundinacea & 90 & 88 & 89 & 84 \\
\hline & Lolium perenne & 10 & 12 & 11 & 13 \\
\hline & Other species - Inne gatunki & & 0 & 0 & 3 \\
\hline \multirow{4}{*}{15} & Festuca pratensis & 50 & 36 & 48 & 41 \\
\hline & Phleum pratense & 30 & 38 & 29 & 32 \\
\hline & Lolium perenne & 20 & 26 & 23 & 26 \\
\hline & Other species - Inne gatunki & & 0 & 0 & 1 \\
\hline
\end{tabular}

The high competitiveness of Lolium perenne in relation to the aggressive Dactylis glomerata is indicated by Grzegorczyk and Trąba (2003). The obtained results do not support the opinion that Lolium perenne is a species that is not suitable for meadow mixtures on peat-muck soils (Kowalczyk et al. 1991). Baryła (2004) studies show that Lolium perenne plays an important role in maintaining the stability of the community with Festuca 
arundinacea, Dactylis glomerata and Phleum pratense. Evaluating the relation between Festuca arundinacea and Festulolium (object 8), it should be noted that the proportion of these species in the sward was appropriate for the composition of the regeneration mixture and remained at a similar level in all years of the study. Such a system of results testifies to the greater competitiveness of Festulolium as compared to Lolium perenne. A similar pattern was found in previous studies (Czyż et al. 2015).

The harvested meadow sward from individual objects was characterized by similar content of dry matter, thus the study was limited to dry matter content only (Table 3 ). In the first year of the full performance (2012), in which three cuts were harvested, their share in the annual yield was as follows: I $-29.7 \%$, II $-26.3 \%$, III $-44.1 \%$, in the second year of the full use, with the four-time mowing of the meadow sward, the individual cuts made up: I $-38.1 \%$, II $-20.1 \%$, III $-29.7 \%$, IV $-12.6 \%$ of annual yield, and in the case of five-time mowing, which took place in 2015 , the share of cuts was as follows: I $-27.4 \%, \mathrm{II}-17.3 \%$, III $-22.2 \%$, IV $-13.5 \%, \mathrm{~V}-19.5 \%$ of the annual yield. Mean values from the objects indicate that annual yields of dry matter increased along with the number of cuts harvested (Table 2). In the case of three cuts (first year of the full performance -2012 ), average yield was $14.19 \mathrm{t} \cdot \mathrm{ha}^{-1}$. In the second year of use (2013), when four cuts were harvested, yields of $15.82 \mathrm{t} \cdot \mathrm{ha}^{-1}$ were achieved, and in the fourth full year of use (2015) with 5 times of meadow mowing, the average annual yield of dry matter was $18.11 \mathrm{t} \cdot \mathrm{ha}^{-1}$. Schmaler and Barthelmes (2012), when comparing the yielding of Festuca arundinacea and Dactylis glomerata in two mowing performance systems, recorded higher yield of dry matter with lower number of cuts than at higher mowing frequencies. In later studies, Schmaler and Barthelmes (2015) compared the yielding of Festuca arundinacea on a three times mowed meadow at a delayed harvest of the first crop, with a four-mowing meadow, and they found higher yield in the first cut, as well as annual yield of dry matter. In the case of three harvests, the share of cuts in the annual yield was: I $-62 \%, \mathrm{II}-16 \%$, III $-22 \%$, and at fourfold: I - 31\%, II - 31\%, III - 11\%, IV - 27\%.

The authors report that on a three times mowed meadow, the obtained annual yield amounted to $-8.5 \mathrm{t} \cdot \mathrm{ha}^{-1} \mathrm{DM}$ and on a four times mowed meadow $-7.5 \mathrm{t} \cdot \mathrm{ha}^{-1}$. In our own research, Festuca arundinacea was also characterized by great production potential. When harvesting three cuts, the second species, besides Festuca arundinacea, was Dactylis glomerata. In the year, in which four cuts were harvested (2013), objects with a high proportion of Festuca arundinacea and Lolium perenne were distinguished. In the case of five-mowing (2015), objects sown both with Festuca arundinacea with Lolium perenne and Festuca arundinacea with Dactylis glomerata should be distinguished. Such a pattern of results allows for positive assessment of Festuca arundinacea with Lolium perenne and Festuca arundinacea with Dactylis glomerata mixtures. Detailed analysis of the relationship between floristic composition of the meadow sward and the level of yielding, it should be stated that on objects sown with Festuca arundinacea only in all years of research, object sown with Hykor cv. was characterized by the highest yield-forming potential. In objects sown with grass mixtures in the first year of the study, objects with a high proportion of Festuca arundinacea and Dactylis glomerata were exceptional - object 9 (Festuca arundinacea 63\% + Dactylis glomerata 36\%) and object 10 (Festuca arundinacea 66\%, Dactylis glomerata 26\% and Lolium perenne 6\%). In 2013, objects 12 and 14 gave the highest yields $-17.31 \mathrm{t} \cdot \mathrm{ha}^{-1}$ and $17.05 \mathrm{t} \cdot$ ha $^{-1}$, respectively (Table 2 ). 
Table 2. Dry matter yields

Tabela 2. Plony suchej masy $\left[\mathrm{t} \cdot \mathrm{ha}^{-1}\right]$

\begin{tabular}{|c|c|c|c|c|c|c|c|c|c|c|c|c|c|c|c|c|c|c|}
\hline \multirow{2}{*}{$\begin{array}{l}\text { Years } \\
\text { Lata }\end{array}$} & \multirow{2}{*}{$\begin{array}{l}\text { Cuts } \\
\text { Pokosy }\end{array}$} & \multicolumn{15}{|c|}{$\begin{array}{l}\text { Number of mixtures } \\
\text { Numery mieszanek }\end{array}$} & \multirow{2}{*}{$\begin{array}{l}\text { Mean } \\
\text { Średnia }\end{array}$} & \multirow{2}{*}{$\begin{array}{l}\text { LSD }_{0.05} \\
\text { NIR }_{0,05}\end{array}$} \\
\hline & & 1 & 2 & 3 & 4 & 5 & 6 & 7 & 8 & 9 & 10 & 11 & 12 & 13 & 14 & 15 & & \\
\hline \multirow{3}{*}{2012} & 1 & 4.31 & 4.63 & 4.33 & 4.61 & 4.06 & 3.59 & 3.79 & 4.23 & 3.99 & 3.88 & 5.32 & 4.12 & 3.94 & 4.37 & 4.13 & 4.21 & r.n. \\
\hline & 2 & 3.29 & 3.59 & 3.57 & 3.02 & 3.45 & 3.91 & 4.07 & 4.10 & 3.78 & 4.25 & 3.66 & 3.70 & 3.69 & 3.56 & 4.26 & 3.73 & r.n. \\
\hline & $\begin{array}{c}\text { Total } \\
\text { Razem }\end{array}$ & 13.78 & 13.78 & 14.54 & 12.97 & 13.11 & 14.09 & 14.73 & 14.64 & 15.55 & 15.92 & 14.86 & 13.56 & 13.72 & 14.12 & 13.45 & 14.19 & r.n. \\
\hline \multirow{3}{*}{2013} & 1 & 5.93 & 5.86 & 6.37 & 5.58 & 5.61 & 5.50 & 5.68 & 5.96 & 6.57 & 6.42 & 7.00 & 6.35 & 6.79 & 6.61 & 4.27 & 6.03 & 2.22 \\
\hline & 4 & 2,29 & 2.10 & 2.07 & 1.95 & 1.89 & 2.04 & 1.93 & 1.72 & 1.97 & 1.77 & 1.98 & 2.02 & 2.19 & 2.18 & 1.72 & 1.99 & 0.53 \\
\hline & $\begin{array}{c}\text { Total } \\
\text { Razem }\end{array}$ & 15.90 & 15.90 & 16.52 & 14.40 & 14.67 & 16.39 & 15.31 & 15.61 & 16.12 & 15.72 & 16.77 & 17.31 & 16.79 & 17.05 & 12.88 & 15.82 & 3.17 \\
\hline \multirow[b]{4}{*}{2015} & 1 & 4.76 & 4.72 & 4.87 & 4.93 & 4.98 & 4.55 & 4.96 & 5.06 & 5.72 & 5.09 & 4.87 & 5.33 & 5.26 & 5.35 & 4.15 & 4.97 & r.n. \\
\hline & 2 & 2.76 & 3.14 & 2.62 & 2.29 & 2.80 & 3.33 & 3.12 & 3.15 & 3.13 & 3.39 & 3.41 & 3.26 & 3.45 & 3.25 & 3.94 & 3.14 & 1.30 \\
\hline & 3 & 3.90 & 4.01 & 4.02 & 3.75 & 3.87 & 4.08 & 4.30 & 4.17 & 4.12 & 3.94 & 4.20 & 3.91 & 4.64 & 3.94 & 3.35 & 4.01 & r.n. \\
\hline & 4 & 2.41 & 2.69 & 2.68 & 2.32 & 2.34 & 2.68 & 2.39 & 2.36 & 2.45 & 2.38 & 2.45 & 2.36 & 2.47 & 2.39 & 2.34 & 2.45 & r.n. \\
\hline
\end{tabular}

r.n. - not significant difference - różnica nieistotna. 
These objects were sown with Festuca arundinacea and Lolium perenne (Table 1). The lowest yield $\left(12.88 \mathrm{t} \cdot \mathrm{ha}^{-1}\right)$ was obtained in object 15 , where three species were present in the sward: Festuca pratensis 48\%, Phleum pratense 29\% and Lolium perenne 23\%. The lowest yields on that object were obtained in the first, second and fourth cut (Table 2). In the fourth year of the full use (2015), objects 9 and 13 were distinguished, with Festuca arundinacea $45 \%$ and Dactylis glomerata $52 \%$ (object 9 ) as well as Festuca arundinacea $76 \%$ and Lolium perenne $21 \%$ (object 13 ). In these objects, dry matter yields were: $19.46 \mathrm{t} \cdot \mathrm{ha}^{-1}$ and $19.61 \mathrm{t} \cdot \mathrm{ha}^{-1}$. In general, that year, the yield variation between various objects ranged from $17.39 \mathrm{t} \cdot$ ha $^{-1}$ in object 15 sown with the mixture: Festuca pratensis $50 \%+$ Phleum pratense $30 \%+$ Lolium perenne $20 \%$, up to $19.61 \mathrm{t} \cdot$ ha $^{-1}$ in object 13 sown with Festuca arundinacea $80 \%$ + Lolium perenne $20 \%$.

The average results from three years of the study covering the first, second and fourth year of the full performance indicate that on the organic soil, the highest yield potential was found for grassy mixtures with Festuca arundinacea, of which the regenerate mixture Festuca arundinacea with Dactylis glomerata - 50\% each, was distinguished. In this object, the average yield of dry matter (from three years of study) was $17.04 \mathrm{t} \cdot \mathrm{ha}^{-1}$. Also in objects sown with Festuca arundinacea, satisfactory yields were obtained, and Hykor cv. deserves a distinction, for which the average yield of dry matter was $16.41 \mathrm{t} \cdot \mathrm{ha}^{-1}$. The lowest yields, especially in the years with four and five-time mowing of the sward, were obtained on the object 15 sown with a mixture of Festuca pratensis with Phleum pratense and Lolium perenne (Table 1). Gregis and Reidy (2015), when studying the suitability of Festuca arundinacea of Belfine cv. for intensive pasture use during the five years of experiment (2008-2012) in the Swiss production farms, found that it is a stable species and suitable for sowing, especially in sites with less rainfall. Although its share in the sward was reduced after 5 years of use to about $50-57 \%$ depending on the pasture, it was much larger than that of Lolium perenne, the share of which in the sward dropped to $33 \%$ under the same production conditions. Mosimann et al. (2010) investigating the growth and development of Lolium perenne containing grass mixtures, as compared to Festuca arundinacea mixtures, reported similar increases in animal weight, indicating the good suitability of Festuca arundinacea for pasture performance. Similar results were obtained by Elsäßer et al. (2015), who compared the grassland mixtures with Dactylis glomerata and Festuca arundinacea. The feed uptake by cattle from plots with Festuca was very similar to Dactylis plots, and even soft-leaf varieties of Festuca arundinacea were more readily grazed. Schrabauer et al. (2014), when examining the yields of 10 species of grasses resistant to periodic drought (including Festuca arundinacea) with other fodder grass species sown in pure sowing in two habitats in the lowlands of the Danube river and the Alps grasslands, found that the highest yield among tested species at many-harvest performance was produced by Festuca arundinacea (average for both habitats of $12.5 \mathrm{t} \cdot \mathrm{ha}^{-1} \mathrm{DM}$ ) with very low secondary succession of other species (only $0.1 \%$ ).

\section{CONCLUSIONS}

1. By characterizing the objects sown with single varieties ('Lipalma', 'Kora', 'Hykor', 'Fawm') of Festuca arundinacea, based on the stability of the floristic composition and uniformity of biomass production during the growing season, it can be stated that Festuca arundinacea is useful for establishing the multi-cut grasslands on organic soils. 
2. Shaping the yielding level in the studied years (2012, 2013 and 2015) allows to asses that Festuca arundinacea with Dactylis glomerata, or Lolium perenne and Festulolium are more effective than Festuca pratensis with Phleum pratense and Lolium perenne.

3. Average results from years of the study indicate that under existing habitat conditions, the greatest production potential was shown by the mixture of Festuca arundinacea $(50 \%)+$ + Dactylis glomerata (50\%) and in objects with Festuca arundinacea only, the highest yield was obtained due to Hykor cv.

\section{REFERENCES}

Baryła R. 1997. Dynamika zmian składu gatunkowego mieszanek łąkowych na glebie torfowo-murszowej w warunkach wieloletnigo użytkowania [Dynamics of changes in species composition of meadow mixtures on peat-muck soils under multi-use conditions]. Ann. UMCS, Sectio E 52, 164-170. [in Polish]

Baryła R. 2004. Przydatność Lolium perenne do mieszanek łąkowych w siedlisku pobagiennym [Suitability of Lolium perenne for meadow mixtures in postboggy habitat]. Łąk. Pol. 7, 9-20. [in Polish]

Baryła R., Kulik M. 2012. Podsiew jako sposób poprawy runi łąk i pastwisk w aspekcie komponowania mieszanek [Overdrilling as a means of improving the sward of meadows and pastures from the perspective of coposing mistures]. Łąk. Pol. 15, 9-28. [in Polish]

Bundessortenamt 2008. Gräser- und Kleearten einschließlich Luzerne, Espaarsette, in: Richtlinien für die Durchführung von landwirtschaftlichen Wertprüfungen und Sortenversuchen. Hannover, Landbuch, Verlag 1-21.

Czyż H., Jänicke H., Kitczak T., Bury M. 2015. Ocena użytków zielonych odnowionych metodą pełnej uprawy położonych na glebie organicznej w dolinie rzeki Randow (Niemcy) [The evaluation of grasslands restored with fullcultivation method and located on organic soil in the valleyof the river Randow (Germany)]. Łąk. Pol. 18, 59-74. [in Polish]

Elsäßer M., Ihrig M., Rothenhäusler S. 2015. Eignung von Rohrschwingel (Festuca arundinacea) in Mischungen unter Beweidung. Grünland effizient und umweltschonend nutzen. Mitteil. Arbeitsgemeinsch. Grünland Futterb. 59, 190-192.

Filipek J. 1970. Zagadnienia wielkości próbek przeznaczonych do analizy botaniczno-wagowej w doświadczeniach łąkarskich [Issues of sample size for botanical-weight analysis in grassland experiments]. Post. Nauk Rol. 4, 85-98. [in Polish]

Gregis B., Reidy B. 2015. Ausdauer von Rohrschwingel unter langjährigen Weidebedingungen. Grünland effizient und umweltschonend nutzen. Mitteil. Arbeitsgemeinsch. Grünland Futterb. 59, 182-185.

Grzegorczyk S. 1993. Produkcyjność mieszanek typu Phalaris arundinacea i Alopecurus pratensis w dolinie Łyny k. Olsztyna [Productivity of mixtures type Phalaris arundinacea and Alopecurus pratensis in Łyna river valley near Olsztyn]. Zesz. Probl. Post. Nauk Rol. 412, 115-120. [in Polish]

Grzegorczyk S., Grabowski K., Benedycki S. 1995. Kształtowanie się zbiorowisk łąkowych w zależności od składu gatunkowego wysianych mieszanek [Formation of meadow communities depending on species composition of sown mixtures]. Ann. UMCS, Sectio E., 61-64. [in Polish]

Grzegorczyk S., Trąba C. 2003. Utrzymywanie się Lolium perenne w runi przemiennych użytków zielonych [The maintenance of Lolium perenne in sward of temporary graslands]. Łąk. Pol. 6, 79-88. [in Polish]

Kamiński J. 2000. Plonowanie, zmiany florystyczne i wartość pokarmowa czterech fenologicznie zróżnicowanych mieszanek łąkowych na glebie torfowo-murszowej [Yielding, floristic change and feeding value of four phenologically different meadow mixture on peat-muck soil]. Wiad. IMUZ 20(4), 23-37. [in Polish]

Kowalczyk J., Kamiński J., Szuniewicz K. 1991. Zasady kształtowania i utrzymywania wysokoprodukcyjnej runi glebowej torfowo-murszowej [Rules for forming and maintaining high-productivity peat-muck soils]. Wiad. IMUZ 16(2), 127-148. [in Polish] 
Mosimann E., Schmied R., Thuillard C.P., Thomet P. 2010. Produktion von Weidebeef auf Kunstwiesen: Bedeutung der Rohrschwingel. Agrarfors. Schweiz 1(5), 194-201.

Niemeläinen O., Jjauhiainen L., Miettinen E. 2001. Yield profile of tall fescue (Festuca arundinacea) in comparison with meadow fescue (Festuca pratensis) in Finland. Grass For. Sci. 56, 249-258.

Nussbaum H. 2015. Physiologische Reife, Siliereignung und Gärqualität von Rohrschwingel im Vergleich zu anderen Gräsern und einer Grasmischung. Grünland effizient und umweltschonend nutzen. Mitteil. Arbeitsgemeinsch. Grünland Futterb. 59, 152-155.

Petersen A. 1981. Die Gräser. Berlin, Akademie-Verlag.

Schmaler K., Barthelmes G. 2012. Methanertragspotenzial von Grünlandbeständen bei unterschiedlicher Intensität der Schnittnutzung. Mitteil. Arbeitsgemeinsch. Grünland Futter. 13, 35-39.

Schmaler K., Barthelmes G. 2015. Chemische Zusammensetzung und Vergärbarkeit von Grünlandaufwüchsen bei unterschiedlicher Schnittnutzung. Grünland effizient und umweltschonend nutzen. Mitteil. Arbeitsgemeinsch. Grünland Futterb. 59, 140-143.

Schrabauer J., Buchgraber K., Moder K., Liebhard P. 2014. Potential of ten alternative grass species under different cutting regimes in Central Europe. J. Kulturpflanzen 66(6), 189-202.

Schubiger F.X., Bosshard H., Lehmann J. 1997. Nährwert von Knaulgras- und Rohrschwingelsorten. Agrarforsch. Schweiz 4(6), 245-248.

Suter D., Hirschi H., Frick R. 2009. Rohrschwingel- und Timothesorten geprüft. Agrarforsch. Schweiz 16(7), 250-255.

Trąba C. 1994. Rolnicza charakterystyka łąk kostrzewowo-wiechlinowych w dorzeczu Łabuńki, w: Kierunki rozwoju łąkarstwa na tyle akutalnego poziomu widzy w najnowszych jego działaniach. Konferencja Naukowa SGGW, Warszawa, 27-28 września 1994. Warszawa, SGGW, 380-389. [in Polish]

Troxler J., Mitztal A. 1983. La fétuque élevée: ses possibilités pour la pâture. Rev. Suis. Agric. 15(3), $127-132$.

\begin{abstract}
The study was carried out in the Randow river valley, on grassland belonging to the farm - Raminer Agrar GmbH \& Co (Germany). Restoration of grassland located on organic soil, was carried out using the full cultivation method. The study included mixtures with the predominant participation of Festuca arundinacea. The assessment included the characteristics of floristic composition, sodding, and general appearance of meadow sward, level of yielding, and uniformity of biomass production during the growing season. The average results from the years of research (2012, 2013 and 2015) showed that the applied mixtures were similar in terms of yield, although the mixture of Festuca arundinacea with Dactylis glomerata - 50\% each, and the mixture of Festuca arundinacea and Lolium perenne - should be distinguished. Of the studied varieties, Festuca arundinacea ('Lipalma', 'Kora', 'Hykor', 'Fawm'), the greatest production potential characterized the Hykor cv. Festuca pratensis and Phleum pratense appeared to be less useful for multi-cutting management. Overall results show considerable usefulness of Festuca arundinacea in mixtures with Dactylis glomerata, Lolium perenne and Festulolium for the regeneration of grassland on organic soils.
\end{abstract}


